\title{
Transglobal Leadership as a Driver for Increasing the Employee Performance
}

\author{
A. Nur Insan ${ }^{1 *}$, Masmarulan R. ${ }^{2}$, Ashariana ${ }^{3}$, Nurfatwa Andriani Yasin ${ }^{4}$ \\ ${ }^{1}$ Departement of Communication Science, Universitas Fajar, Indonesia \\ ${ }^{2,4}$ Department of Management Science, Sekolah Tinggi Ilmu Ekonomi Tri Dharma Nusantara, Indonesia \\ ${ }^{3}$ Departement of Public Administration, Universitas Pejuang Republik Indonesia, Indonesia
}

\section{Keywords: \\ Transglobal Leadership, \\ Motivation, Organizational \\ Culture, Commitment \\ Organizational, Performance}

\section{Received}

06 December 2020

Received in revised form

01 January 2021

Accepted

03 January 2021

*Correspondence:

anurinsan9@gmail.com

\begin{abstract}
This study aims to analyze and explain the influence of transglobal leadership on employee work motivation, the influence of transglobal leadership on organizational culture, the effect of transglobal leadership on organizational commitment, the effect of transglobal leadership on employee performance, the influence of motivation on employee performance, the influence of organizational culture on employee performance, and the influence of organizational commitment on employee performance. This research is an explanatory study using a survey methodology. This research was conducted in 42 cooperative units of government agencies in Makassar City. The population is 418 cooperative employees. The sample was taken using the Stratified Random Sampling method of 180 people. Data were collected through questionnaires and interviews. Data analysis used Partial Least Square (PLS). The results obtained from testing of the seven hypotheses showed that there were six hypotheses accepted because they had a positive and significant effect and one hypothesis was rejected because it had an insignificant effect, namely the effect of organizational commitment on employee performance. Cooperative managers need to pay more attention to relationships with customers, review fair wages and regulations and rewards to employees, increase understanding of shared values and meanings, increase understanding of aspects of work, and improve employee positive attitudes.
\end{abstract}

(C)CIKD Publishing

In the early 19th century in developed countries such as America and Europe, humans began to form organizations which is an indispensable element in human life. As time goes by, organizations began to advance in developed countries. Likewise, in Indonesia at the end of the 19th century, organizations developed rapidly. In this regard, there are various leadership styles such as autocratic, democratic, militaristic, transformational, and transactional leadership. In 2012, Sharkey et al. formulated transglobal leadership. Leadership is the ability to influence a group to achieve a 
predetermined vision or set of goals (Robbins, 2003). At the same time, the community felt the need to establish cooperatives in both government agencies and private cooperatives with the presence of cooperatives; the community has felt the role and benefits of cooperatives in Indonesia, although with different degrees and intensities. Achievement Cooperatives are cooperatives that outdo in achieving their performance both from organizational aspects, management aspects, productivity aspects, and beneficial aspects. In this case, the government determines the existence of cooperatives in Indonesia with Number: 06 / Per / M. KUKM / V / 2006) through the Decree of the State Minister for Cooperatives and Small and Medium Enterprises. In East Java, Cooperatives and SMEs contributed 53.04\% (IDR 469.950 trillion) to East Java's GRDP (Office of Cooperatives and SMEs, 2018). Njotoprajitno (2011) stated that what is dishonest in cooperatives is a human resource problem.

Anoraga (2008) argues that cooperative development must start from the leadership sector where leaders need to be selected and developed for visionary, alertness, and responsiveness, to be able to harmonize, motivate and empower the management, employees, and members of the cooperative. Kartikandari (2002) posited that motivation has a positive effect on employee performance. Cooperatives in Indonesia, especially cooperatives in South Sulawesi Province, need leaders who can bring cooperative continuity and achieve goals. One of the good leadership styles is transglobal leadership even though the leadership is still relatively new. Transglobal leadership motivates employees so that employees are enthusiastic about working. Vogel (2011) found that transglobal and transactional leadership influences motivation. This proves that transglobal leadership can increase employees' motivation so that transglobal leadership will be able to influence and support the development of human resource competencies in organizations, especially in cooperatives in Indonesia. Furthermore, cooperatives also need the presence of leaders that can serve their members and employees according to the cooperative principles. Transglobal leadership is expected to increase employees' motivation/morale. Calmness, coolness, beauty, trust, and harmony describes the existing leadership in the organization and the culture that exists in the organization.

With a strong culture, the organization can survive and continue to improve employee performance in the organization. Nystrom (1993) found that organizational culture and organizational commitment impact employee performance. Likewise, Fey and Denison (2000) found that organizational culture affects employee performance. However, if the organizational culture is weak, it does not affect organizational commitment and employee performance. The phenomenon that occurs in cooperatives in the city of Makassar, South Sulawesi Province is that the management of cooperatives is not optimal because the skills and competencies of leaders still need to be improved in managing human resources. In addition, employee rewards are still low so that organizational commitment is also low which ultimately affects employee performance.

Employee performance is also related to organizational culture. If the organizational culture and work culture is strong and upheld by employees, it can improve employee performance. The organizational culture that is continuously applied in cooperative organizations is also a basic human characteristic as a general characteristic of work culture in Indonesia. According to Setyadi (2005), good work culture can accommodate conflicts in cooperative organizations and will be a driving force for the creation of a productive work process.

Although empirical research on transglobal leadership is still scarce, Drury (2004) proves that there is a negative relationship between transglobal leadership and organizational commitment, and 
there is a relationship between transglobal leadership and organizational commitment. Organizational commitment is a psychological condition that characterizes the relationship between employees and the organization which has implications for the employee's decision to continue or quit as a member of the organization (Meyer \& Allen, 1991). Organizational commitment is one of the factors that can affect the success of an organization facing an increasingly complex environment. Employees who have high organizational commitment will identify their interests with the interests of the organization, be seriously involved in work, and have loyalty and affection for achieving organizational goals. Age and gender and education are often determinants of organizational commitment (Becker, 1960). Employees over forty years of age tend to have high organizational commitment because they are less likely to get jobs in other organizations. Organizational commitment is related to employee performance. Research by Wasti and Can (2008) revealed that organizational commitment has a significant effect on employee performance, whereas if the organizational commitment is low it will reduce employee performance.

Based on these descriptions, this study aims to analyze and explain the influence of transglobal leadership on motivation, the effect of transglobal leadership on organizational culture, transglobal leadership on organizational commitment, transglobal leadership on employee performance, motivation on employee performance, organizational culture on employee performance, and organizational commitment. on employee performance.

The originality of this study is that transglobal leadership is a leadership style suitable for cooperatives, although the theory is still weak. Researchers conducted an empirical test of leadership styles (transformational, transactional, and laissez-faire) in cooperatives that have been carried out before, but research on transglobal leadership style which is associated with the performance of cooperative employees is still rare. Therefore, researchers conducted more comprehensive research on transglobal leadership and cooperative employee performance. The mediating effect of the three variables, namely motivation, organizational culture, and organizational commitment, also differentiates this study from previous studies.

Theoretically, Sharkey et al. (2012) state that these three variables should be contained in the transglobal type of leadership, which transactional leadership does not yet have (Kartasasmita, 1996). Likewise, transformational leadership by Friedman and Macaulay (1969) which only sees the aspect of the transaction system or the transformation between leaders and subordinates is still local (scale). This has not taken into account the global aspects related to the broader public interest. Thus, it can be concluded that the transglobal leadership theory needs to be applied to cooperatives in Indonesia.

Transglobal leadership has a high level of intelligence both cognitive, moral, business, cultural, global, and emotional, and is superior to some previous leadership theories (transactional or transformational). Besides, there is a paucity of research that has examined the effect of transglobal leadership on work motivation, organizational culture, organizational commitment, and employee performance.

\section{Literature Review}

\section{Leadership}

Pasolong (2008) argues that leadership is the ability to influence others through direct or indirect communication to mobilize people with a sense of thoroughness and the ability to follow the leader's wishes. Furthermore, Pasolong (2008) also states that the leadership function includes two 
main areas, namely the achievement of organizational goals (i.e., initiation of support and evaluation information arrangements) and the cohesiveness of the people they lead (i.e., encouraging, expressing feelings, harmonizing, compromising, and maintaining gates and establishing gates standard). As time goes by, organizations develop and leadership varies as Sharkey et al. (2012) analyze theoretical problems regarding transactional or transformational leadership which are classified into local leadership types. In its early development, the leadership style appeared in the form (version) of local which was unable to reach global aspects. Therefore, Sharkey et al. (2012) construct a more global type of leadership known as transglobal leadership. Transglobal leadership transcends cultural and national boundaries, which is universal and contributes greatly to the spirit of humanity to change human civilization. Transglobal leaders make people's lives more attractive, more beautiful, more prosperous, more dignified, or better. A transglobal leader takes the idea and adapts to a new, wider, and more complex environment. A transglobal leader is more likely to support and help define a unique approach to work. Whereas local leaders do a good job of keeping a stable operation and building like-minded teams that will achieve goals repeatedly and reliably. Furthermore, the image of the transglobal leadership model can be seen in Figure 1:

\section{Transglobal ${ }^{m}$ Leadership Model}

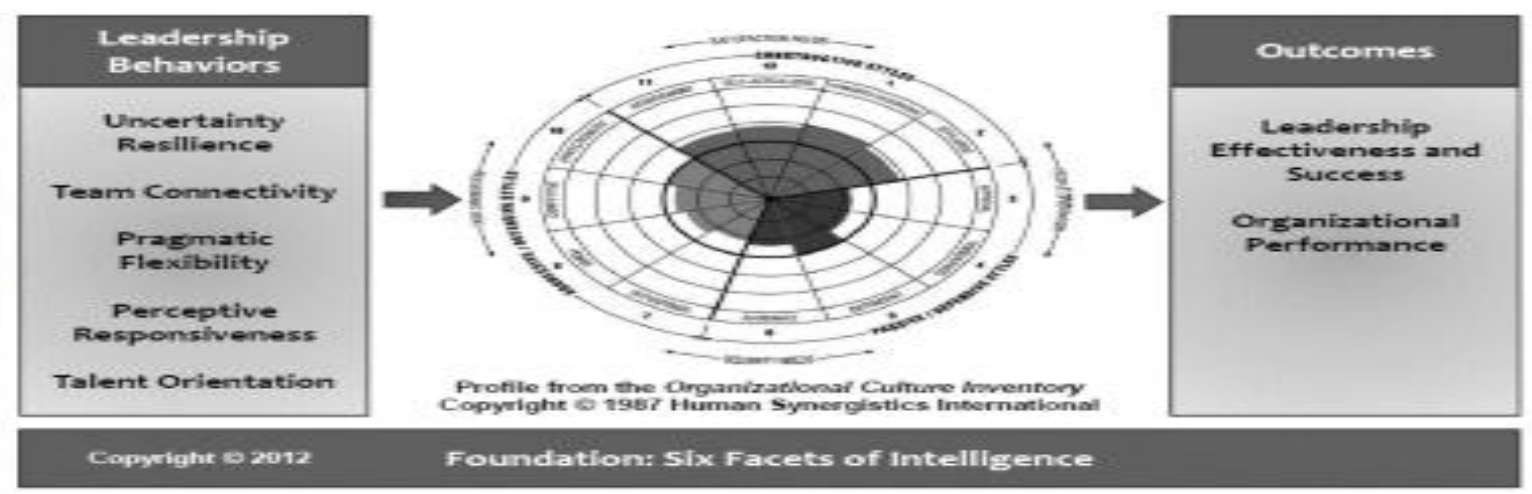

Figure 1. Transglobal leadership model

Figure 1 explains the relationship between transglobal leadership behavior and organizational success (in this case, employee performance). Sharkey et al. (2012) explain that transglobal leadership styles have five characteristics, namely uncertainty resilience, team connectivity, pragmatic flexibility, perspective responsiveness, and talent orientation that can increase effectiveness and success. Thus, transglobal leadership will lead to better organizational performance results. Theoretically, it illustrates strongly the evidence for the relationship between transglobal leadership and employee performance.

\section{Motivation}

Motivation is a strong desire from a person that influences one's thoughts and behavior. Maslow's motivation theory (2010) states that humans have five basic needs, namely: physical needs (clothing, food, shelter, social and health needs). The need for security, social needs (love, gathering, friends, need for self-esteem (respect and trust), and need for self-actualization) develop their full potential 
Robbins and Coulter (1993) define motivation as a process that produces intensity, direction, and individual persistence to achieve a goal. With this motivation, a person will be able to increase his efforts as much as possible, with the abilities they have, so that the achievement will be maximized. Motivation is related to employee performance. Employee performance is a function of ability, motivation, and opportunity (Robbins, 2003). Reliable performance cannot only be achieved by ability alone but a combination of effort and ability (knowledge, skills, training, etc.). In this study, the motivation was measured by indicators put forward in Luthans's (2002) study. They include: valence, expectations, and instruments, with the following points: (1) The Valence Indicator consists of Trust, True, and Comfort, (2) Expectation indicators consist of Activating, Recognizing, and Enjoying, (3) Instrumental indicators consist of Wages/salaries, rules of achievement awards, opportunities, and forms of appreciation.

\section{Organizational Culture}

Schein (1985, as cited in Luthans, 2002) argues that organizational culture is a common pattern of assumptions that companies generally get when solving internal and external adjustment problems, working quite well that are considered legitimate. Likewise, Robbins (2006) explains that organizational culture is a system of shared meanings of primary values shared and valued by organizations that function to create clear differences between one organization and another, creating a sense of identity for organizational members. Also, organizational culture facilitates collective commitment to the organization, increases the stability of the social system, creates meaning-making, and controls mechanisms that guide, shape the attitudes, and behavior of members of the organization.

Robbins (2006) emphasizes the existence of 10 key characteristics that are at the core of organizational culture: Member identity, group emphasis, focus on people, unit integration, control, risk tolerance, reward criteria, conflict tolerance, edge-to-edge orientation, and open-focus systems. Robbins (2006) also explains the benefits of organizational culture, namely limiting roles that differentiate between organizations, creating a sense of identity for members, prioritizing common goals, and maintaining organizational stability. Likewise, Kotter and Heskett (1992) stated that there are three types of organizational culture such as strong culture and weak culture, harmonious and strategic culture, and adaptive and non-adaptive culture. According to Robbins (2006), there are six dimensions of organizational culture, namely the relationship with the environment, time orientation, human nature, activity orientation, responsibility, and variations in the concept of space.

Cooperative is one of the economic organization forms that is currently growing rapidly in Indonesia carrying multiple missions (social and economic) so that the organizational culture that develops in the cooperative is also different from the organizational culture that thrives on other forms of economic organizations such as SOEs and POEs (privately owned enterprises) oriented to seek profit.

\section{Organizational Commitment}

Commitment is defined as "an employee level of attachment to some aspect of work" (Allen, Meyer, \& Smith, 1993). That is, organizational commitment is described as the level of employee engagement in several aspects of work. Employment commitment can be classified into three groups, namely: work/job commitment, career / professional commitment, and organizational commitment to the organization. Organizational commitment is the psychological 
bond that employees have in the organization related to the alignment of goals and values; the organization which allows employees to stay in the organization. Organizational commitment is a sense of identification, involvement, and loyalty displayed by employees to the organization or organizational unit (Gibson, 1982). Likewise, Mowday et al. (1982) explained that organizational commitment is a dimension of behavior that can be used to assess the tendency of employees to survive as members of the organization

Organizational commitment is an attitude that reflects employee loyalty to the organization and a continuous process where organizational actors express their concern for the organization and their desire to be successful and prosperous (Luthans, 2001). The main theoretical approaches emerge from previous research on organizational commitment, namely: the attitude approach; according to the approach to organizational commitment, it shows the problems of engagement and loyalty (Muthuveloo \& Rose, 2005). Furthermore, Minner (1998) concluded that four factors influence commitment, namely personal factors, job characteristics, structural characteristics, and work experience. Meanwhile, Kanter (1999) suggested three forms of commitment, namely (1) Continuance Commitment; commitment related to member dedication, (2) Cohesion Commitment; member commitment to the organization as a result of social relations with members and other members, and (3) Commitment Control; commitment of members to the organization that directs member behavior to the desired goal.

\section{Performance}

Robbins (1993) states that employee performance is a function of the interaction between ability and motivation. If the employee's ability is low, it will affect the employee's performance. Likewise, Bernadin and Russel, (1993) explain six criteria that can be used to measure individual/employee performance, namely quality, work results, the number of work results, timeliness, costeffectiveness, ability to work, and ability to build work relationships. Another definition states that employee performance is related to organizational goals such as quality, efficiency, and several other criteria of effectiveness (Gibson, 1982).

Likewise, Soedjono (2005) mentions six criteria that can be used to measure individual employee performance, namely quality, quantity, timeliness, effectiveness, independence, work commitment, and employee responsibility to the organization. Employee performance is a description of the level of achievement of the implementation of a program or policy in realizing the goals, objectives, vision, and mission of the organization as outlined in the strategic planning of an organization (Muheriono, 2012).

\section{Method}

This research is explanatory with a survey methodology. As shown in Table 1, the research sample included 180 respondents from 42 cooperative units in government agencies of Makassar city, South Sulawesi Province. The sampling was conducted using the stratified random sampling method. Stratified Random Sampling is a sampling method in which a heterogeneous population is divided into layers (strata) that are completely separated from each other, and from each stratum, a random sample can be taken (Sugiyono, 2010). Table 2 presents the respondent's data based on gender, age, educational level, and years of service. 
Table 1

The Number of Respondents based on their Position in 42 Cooperative Units

\begin{tabular}{lccc}
\multicolumn{1}{r}{ Position } & Total & Sample Calculations & Total Samples \\
\hline Manager & 59 & $(59 / 418) \times 180$ & 25 \\
assistant manager & 70 & $(70 / 418) \times 180$ & 30 \\
Staff & 289 & $(289 / 418) \times 180$ & 125 \\
TOTAL & 418 & & 180 \\
\hline
\end{tabular}

Table 2

Respondents' Demographic

\begin{tabular}{clccc}
\hline & & Men & Woman & Total \\
\hline Age & 25-39 Years & 56 & 33 & 89 \\
& 40-50 Years & 45 & 46 & 91 \\
Educational stage & Senior High School & 79 & 49 & 128 \\
& Bachelor & 28 & 24 & 52 \\
\multirow{2}{*}{ Years of service } & $>6$ Years & 36 & 29 & 65 \\
& 7-15 Years & 61 & 54 & 115 \\
\hline
\end{tabular}

Data collection was carried out using the questionnaire method and interview method. The questionnaire in this study was made directly by the researcher who adjusted to the conditions of the cooperative under study. The items of the questionnaire consist of indicators of the constructs (variables) under study, and instruments used to measure research variables using a Likert scale. The constructs in the questionnaire include indicators as follows:

1. Transglobal Leadership Variables (X1) whose indicators include Uncertainty Resistance (X1.1), Team Connectivity (X1.2), Pragmatic Flexibility (X1.3), Talent Orientation (X1.4).

2. Motivation Variables (Y1) with Valence Indicators (Y1.1), Expectation (Y1.2), Instrumental (Y1.3).

3. Organizational Culture Variables (Y2) with indicators of uncertainty avoidance (Y2.1), Masculine and feminine (Y2.2), Individualism and togetherness (Y2.3), Power distance (Y2.4).

4. Commitment Variables (Y3) with indicators Desire (Y3.1), Willingness (Y3.2), Confidence (Y3.3).

5. Performance Variables (Y4), with indicators measuring work results (Y4.1), work behavior (Y4.2), personal characteristics (Y4.3).

The interviews were conducted by researchers through dialogues with respondents. The interview was an unstructured interview which only contained an outline that would be asked only about the conditions of the cooperative where the respondent worked. The results of this interview would help researchers in seeing the conditions and developments of the cooperative.

In this study, data analysis was run employing Partial Least Square (PLS) approach. PLS is a Structural Equation Modeling (SEM) equation model based on components or variants. PLS is an alternative approach that shifts from a covariance-based to variant-based SEM approach. First, the model determines the relationship between latent variables (structural model). Second, the external model determines the relationship between latent variables and the measurement model. Third, the weight relationship where the case value of the latent variable can be estimated (Yasin et al., 2019) The main hypotheses of this research are as follows:

$\mathbf{H}_{1}$ : Transglobal leadership has a significant effect on motivation.

$\mathbf{H}_{2}$ : Transglobal leadership has a significant effect on organizational culture.

$\mathbf{H}_{3}$ : Transglobal leadership has a significant effect on organizational commitment. 
H4: Transglobal leadership has a significant effect on employee performance.

H5: Motivation has a significant effect on employee performance.

H6: Organizational culture has a significant effect on employee performance.

H7: Organizational commitment has a significant effect on employee performance.

\section{Results and Discussion}

\section{Evaluation of Measurement (Outer) Model}

The measurement model is a sub-model in SEM which is used to evaluate the quality of the relationship between latency and its manifest variables. Confirmatory Factor Analysis (CFA) itself is known as a statistical tool that is useful in finding the construct form of a set of manifest variables or testing a variable on the manifest assumptions that construct it. So that confirmatory analysis is used to test a variable theory on the manifest or indicators that build it, where the variable is assumed to be measured only by these indicators (Ferdinand, 2002). CFA is a factor analysis that is used with the aim of testing or empirically confirming the measurement model, which aims to test whether the data built has the validity and reliability of the latent construct-forming indicators. In Smart PLS, CFA is built from the validity test and Reliability test, so that to find out whether the CFA is feasible or not, it can be seen from the value of the validity test and the Reliability test which must meet the standards (Maruyama, 1998). The validity test itself is seen from the Outer Loading, Cross Loading, Average Variance Extracted (Ave) values. Meanwhile, the Reliability test is seen from the Composite reliability value and Cronbach's Alpha.

\section{Validity Test}

An indicator is declared valid if it has a loading factor above .5 against the intended construct. Table 3 shows that the loading factor provides a value above the recommended value of .5. The smallest value is .69 for the Avoidance of uncertainty (Y2.1) indicator. It means that the indicators used in this study are valid or have met convergent validity. Figure 1 presents the loading factor for each indicator in the research model.

Table 3

Result for Outer Loading

\begin{tabular}{|c|c|c|c|c|c|}
\hline & $\begin{array}{l}\text { Transglobal } \\
\text { Leadership }\end{array}$ & Motivation & $\begin{array}{l}\text { Organizational } \\
\text { Culture } \\
\end{array}$ & Commitment & Performance \\
\hline Uncertainty resilience (X1.1 & .74 & & & & \\
\hline Team Connectivity (X1.2) & .87 & & & & \\
\hline Pragmatic Flexibility (X1.3) & .70 & & & & \\
\hline Talent Orientation (X1.4) & .76 & & & & \\
\hline Valence (Y1.1) & & .86 & & & \\
\hline Expectation (Y1.2) & & .87 & & & \\
\hline Instrumental (Y1.3) & & .87 & & & \\
\hline Avoidance of uncertainty (Y2.1) & & & .69 & & \\
\hline Masculine and feminine (Y2.2) & & & .83 & & \\
\hline Individualism and togetherness (Y2.3) & & & .80 & & \\
\hline Distance of power (Y2.4) & & & .86 & & \\
\hline Desire (Y3.1) & & & & .83 & \\
\hline Willingness (Y3.2) & & & & .80 & \\
\hline Confidence (Y3.3) & & & & .86 & \\
\hline Work result (Y4.1) & & & & & .98 \\
\hline Work behavior (Y4.2) & & & & & .98 \\
\hline Personal Traits (Y4.3) & & & & & .63 \\
\hline
\end{tabular}

Source: PLS data processing (2020) 


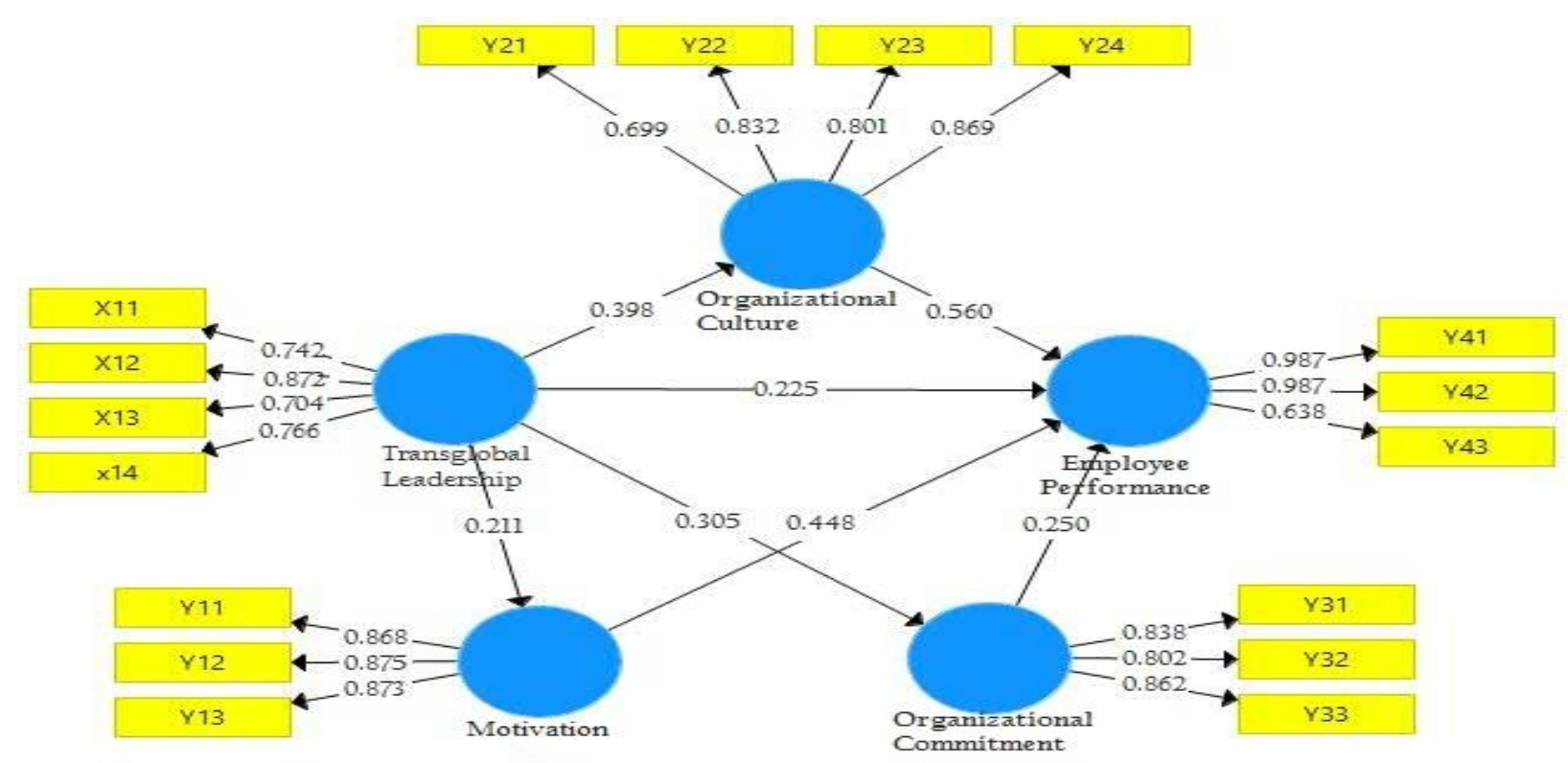

Figure 2. SEM-Pls measurement model (outer model)

Furthermore, reflective indicators also need to be tested for discriminant validity by cross loading as shown in Table 4. An indicator is declared valid if it has the highest loading factor for the intended construct compared to the loading factor for other constructs. Table 4 shows that the loading factor for the Transglobal Leadership indicator (X1.1 to X1.4) has a higher loading factor for the Transglobal Leadership construct than other constructs. As an illustration, the loading factor of Uncertainty resilience (X1.1) to Transglobal Leadership is .74 which is higher than the loading factor of Valence (Y1.1) of .43, Avoidance of uncertainty (Y2.1) that is .21, and Desire (Y3.1) of .42. The same is seen in other indicators. Thus, latent constructs predict indicators on their block better than indicators on other blocks.

Table 4

Result for Cross Loading

\begin{tabular}{|c|c|c|c|c|c|}
\hline & $\begin{array}{l}\text { Transglobal } \\
\text { Leadership }\end{array}$ & Motivation & $\begin{array}{l}\text { Organizational } \\
\text { Culture }\end{array}$ & Commitment & Performance \\
\hline Uncertainty resilience (X1.1) & .74 & .14 & .51 & .47 & .47 \\
\hline Team Connectivity (X1.2) & .87 & .53 & .26 & .44 & .19 \\
\hline Pragmatic Flexibility (X1.3) & .70 & .39 & .56 & .31 & .39 \\
\hline Talent Orientation (X1.4) & .76 & .39 & .14 & .22 & .39 \\
\hline Valence (Y1.1) & .43 & .86 & .12 & .44 & .37 \\
\hline Expetation (Y1.2) & .21 & .87 & .14 & .42 & .47 \\
\hline Instrumental (Y1.3) & .62 & .87 & .24 & .45 & .52 \\
\hline Avoidance of uncertainty (Y2.1) & .21 & .38 & .69 & .34 & .53 \\
\hline Masculine and feminine (Y2.2) & .43 & .46 & .83 & .34 & .15 \\
\hline Individualism and togetherness (Y2.3) & .21 & .53 & .80 & .33 & .14 \\
\hline Distance of power (Y2.4) & .31 & .25 & .86 & .33 & .19 \\
\hline Desire (Y3.1) & .42 & .38 & .24 & .83 & .42 \\
\hline Willingness (Y3.2) & .43 & .48 & .23 & .80 & .24 \\
\hline Confidence (Y3.3) & .21 & .53 & .15 & .86 & .26 \\
\hline Work result (Y4.1) & .42 & .51 & .21 & .11 & .98 \\
\hline Work behavior (Y4.2) & .43 & .54 & .23 & .45 & .98 \\
\hline Personal Traits (Y4.3) & .47 & .46 & .33 & .54 & .63 \\
\hline
\end{tabular}

Source: PLS data processing (2020)

Another method to see discriminant validity is to look at the square root of the Average Variance Extracted (AVE) value. The recommended values are above .5. As indicated in Table 5, the AVE values are above .5 for all constructs contained in the research model. The lowest value of AVE is .60 for the Motivation and Organizational Culture construct. 
Table 5

Average Variance Extracted (AVE)

\begin{tabular}{lc}
\hline & Average Variance Extracted (AVE) \\
\hline Transglobal Leadership (X1) & .73 \\
Motivation (Y1) & .60 \\
Organizational Culture (Y2) & .60 \\
Commitment (Y3) & .77 \\
Performance (Y4), & .89 \\
\hline Source: PLS data processing (2020)
\end{tabular}

\section{Reliability Test}

A Reliability test is done by looking at the composite reliability value of the indicator block that measures the construct. The result of composite reliability shows the required value if it is above .7. The reliability test can also be strengthened with Cronbach's Alpha and the nested value is above .6. Table 6 presents data on the value of Composite reliability and Cronbach's Alpha from five indicators. As shown in Table 6, all the Composite Reliability and Cronbach's Alpha values of all indicators meet the standards so that it can be concluded that all indicators are reliable. Based on the results of the analysis of the validity test and reliability test, it can be said that the CFA is feasible or the research model has good suitability.

Table 6

Composite Reliability and Cronbach's Alpha

\begin{tabular}{lcc}
\hline & Composite Reliability & Cronbach's Alpha \\
\hline Transglobal Leadership (X1) & .82 & .74 \\
Motivation (Y1) & .85 & .77 \\
Organizational Culture (Y2) & .85 & .76 \\
Commitment (Y3) & .93 & .89 \\
Performance (Y4), & .97 & .96 \\
\hline
\end{tabular}

Source: PLS data processing (2020)

\section{Structural Model Testing (Inner Model)}

After the estimated model meets the Outer Model criteria, the next step is to test the structural model (Inner model). Table 7 demonstrates the $\mathrm{R}^{2}$ values of the constructs. As presented in Table 7 , measurement of the endogenous variable, namely motivation (Y1) obtained $\mathrm{R}^{2}$ of .50 or $50.89 \%$. This shows that $50.89 \%$ of Motivation (Y1) is influenced by Transglobal Leadership (X). Measurement of the endogenous variable, namely Organizational Culture (Y2) obtained $\mathrm{R}^{2}$ of .67 or $67.50 \%$. This shows that $67.50 \%$ of Organizational Culture (Y2) is influenced by Transglobal Leadership (X) and Motivation (Y1). Measurement of the endogenous variable, namely Commitment (Y3) obtained $\mathrm{R}^{2}$ of .70 or $70.50 \%$. This shows that $70.50 \%$ Commitment (Y3) is influenced by Transglobal Leadership (X), Motivation (Y1), and Organizational Culture (Y2). Measurement of the endogenous variable, namely performance (Y4) obtained $\mathrm{R}^{2}$ of .77 or $77.50 \%$. This shows that 77.50\% Performance (Y4) is influenced by Transglobal Leadership (X), Motivation (Y1), Organizational Culture (Y2), and Commitment (Y3)

Table 7

$R^{2}$ Results

\begin{tabular}{ll}
\hline & $\mathrm{R}^{2}$ \\
\hline Transglobal Leadership (X1) & .50 \\
Motivation (Y1) & .67 \\
Organizational Culture (Y2) & .70 \\
Commitment (Y3) & .77 \\
Performance (Y4), &
\end{tabular}


Thus, the predictive relevance $\left(\mathrm{Q}^{2}\right)$ is obtained as follows:

$\mathrm{Q}^{2}=1-\left(1-\mathrm{R}^{2}\right)\left(1-\mathrm{R} 2^{2}\right) \ldots\left(1-\mathrm{R}_{\mathrm{P}}^{2}\right)$

$\mathrm{Q}^{2}=1-(1-0.5089)(1-0.6750)(1-0.7050)(1-0.7750)$

$\mathrm{Q}^{2}=0.9894$.

The calculation result shows the predictive-relevance value of .98 or $98.94 \%$. The prediction relevance score of $98.94 \%$ also shows that the diversity of data that can be explained by the model is $98.94 \%$ or in other words, the information contained in the data is $98.94 \%$ can be explained by the model. While the remaining $1.06 \%$ is explained by other variables (which are not included in the model) and error. From the phenomena above, the model deserves to be said to have a relevant predictive value.

Next is the structural model interpretation. The structural model presents the relationship between the research variables. The structural model coefficient represents the magnitude of the relationship between one variable and another. There is a significant effect between one variable and another if the P-value $<.05$ or based on the T-Count value $<\mathrm{T}$-Table. With the structural model interpretation in Table 8, we can answer hypothesis testing and determine the significance of the effect of exogenous variables on endogenous variables. SEM-PLS explains that the hypothesis measures the significance by comparing the T-table and T-statistic values. If the calculated $\mathrm{T}$ value is greater than the $\mathrm{T}$ table value, then the hypothesis is accepted. The confidence level of 95 percent (or $5 \%$; <.05) for the two-way hypothesis is $>1.96$.

The coefficient value of the relationship between variables can be seen in Table 8 . The results indicated that Transglobal Leadership (X1) has a unidirectional and significant relationship to Motivation (Y1), $\beta=.21, t=14.06$ (t count > 1.96). Transglobal Leadership (X1) has a unidirectional and significant relationship with Organizational Culture (Y2), $\beta=.39, t=47.06(\mathrm{t}$ count > 1.96). Transglobal Leadership (X1) has a unidirectional and significant relationship with the Organization of Commitment (Y3), $\beta=.30, t=35.22$ ( $\mathrm{t}$ count $>1.96$ ). Transglobal Leadership (X1) has a unidirectional and significant relationship with Employee Performance (Y4), $\beta=.22, t$ $=2.80$ ( $\mathrm{t}$ count $>1.96$ ). Motivation (Y1) has a unidirectional and significant relationship with Employee Performance (Y4), $\beta=.44, t=5.63$ ( $\mathrm{t}$ count>1.96). Organizational Culture (Y2) has a unidirectional and significant relationship with Employed Performance (Y4), $\beta=.56, t=8.42(\mathrm{t}$ count>1.96). Organizational Commitment (Y3) has a unidirectional relationship with Employed Performance (Y4), $\beta=.25$, but it is not significant because the $t$-count value is only 1.81 ( $t$ count $<1.96)$.

Table 8

Path Coefficients (Mean, STDEV, T-Values)

\begin{tabular}{llccccc}
\hline & & $\begin{array}{c}\text { Original } \\
\text { Sample } \\
(\mathrm{O})\end{array}$ & $\begin{array}{c}\text { Sample } \\
\text { Mean } \\
(\mathrm{M})\end{array}$ & $\begin{array}{c}\text { Standard } \\
\text { Deviation } \\
(\text { STDEV) }\end{array}$ & $\begin{array}{c}\text { T Statistics } \\
(\mid \mathrm{O} / \mathrm{STDEV})\end{array}$ & $\begin{array}{c}\text { Information } \\
\end{array}$ \\
\cline { 2 - 7 } Transglobal Leadership(X1) & $\rightarrow$ Motivation(Y1) & .21 & .21 & .05 & 14.06 & Significant \\
Transglobal Leadership (X1) & $\rightarrow$ Organizational Culture(Y2) & .39 & .39 & .02 & 47.06 & Significant \\
Transglobal Leadership (X1) & $\rightarrow$ Organizational Commitment(Y3) & .30 & .31 & .03 & 35.22 & Significant \\
Transglobal Leadership (X1) & $\rightarrow$ Employee Performance(Y4) & .22 & .23 & .13 & 2.80 & Significant \\
Motivation (Y1) & $\rightarrow$ Employee Performance(Y4) & .44 & .45 & .08 & 5.63 & Significant \\
Organizational Culture (Y2) & $\rightarrow$ Employee Performance(Y4) & .56 & .56 & .11 & 8.42 & Significant \\
Organizational Commitment (Y3) $\rightarrow$ Employee Performance(Y4) & .25 & .25 & .14 & 1.81 & Not Significant \\
\hline
\end{tabular}

Source: PLS data processing (2020) 


\section{Discussion}

\section{Effect of Transglobal Leadership (X1) on Motivation (Y)}

The results of the analysis show that Transglobal Leadership has a significant effect on motivation. The positive coefficient indicates a one-way relationship. This means that the increase in transglobal leadership (X) has a significant effect on increasing motivation (Y1), the higher the transglobal leadership value (X1), the higher the motivation value (Y11).

The results of this study support the theory of Greenleaf's Transglobal Leadership (1970), wherewith the main element serving others, leaders influence, encourage, and empower others to do better. To realize empowerment, leaders must attract, not just encourage, because the power that is drawn will strengthen and motivate employees. The findings of this study support the empirical evidence of the model developed by Vogel (2011) wherein his thesis, it is proven that the quantitative and qualitative approaches of transglobal and transactional leadership affect motivation. Although it remains unanswered which of the two types of leadership, which are applied appropriately to the public sector, can influence employee motivation, and how to measure their motivation. However, Koh et al., (1995) found that there is a weak positive relationship between transglobal leadership and normative commitment and normative commitment has a positive effect on employee behavior and reactions but does not have a significant effect on affective commitment.

\section{Effect of Transglobal Leadership (X1) on Organizational Culture (Y2)}

The results showed that Transglobal Leadership has a significant effect on Organizational Culture. This means that the higher the value of Transglobal Leadership, the higher the value of Organizational Culture.

This study supports and empirically proves Russell and Stone's (2002) model that organizational culture and employee attitudes can influence the effectiveness of Transglobal Leadership and vice versa. If "serving" is done continuously and internalized in a group, it will become a value that is understood and be able to direct employee behavior. The role of Transglobal Leadership affects Organizational Culture related to organizational development and change and touches on employee education and training activities so that employees have strong cultural values, adaptive, and following the demands of the business world. This study also supports the theory of Organizational Culture as the normative glue of Tichy (1982) that culture has a very strategic role to encourage and increase organizational effectiveness, depending on the leader. Leadership can develop various attitudes and behaviors that lead to a cultural environment. Avolio and Bass (2004) explain that variations in attitudes and cultures stem from different job ideas from different cultural-influenced leadership styles.

\section{Effect of Transglobal Leadership (X1) on Organizational Commitment (Y3)}

Based on the analysis, it is known that Transglobal Leadership has a significant influence on Organizational Commitment. This means that the higher the value of Transglobal Leadership, the higher the value of Organizational Commitment.

This study supports Agarwal (2013) who argues that behavior (as a strong component of serving leadership) is closely related to Organizational Commitment. This study extends the findings that there is a positive influence between leadership style and organizational commitment. Bateman and Strasser (1984) and Bono and Judge (2003) also expand their findings and prove that in the XYZ 
organization in Malaysia there is a significant positive relationship between Transglobal Leadership and Organizational Commitment. However, the findings of this study do not support Drury (2004) who found that there is a significant negative relationship between Transglobal Leadership and Organizational Commitment. Hernawati, A (2017) in her research proves that there is no relationship between Transglobal Leadership and Organizational Commitment, but in general, almost all literature proves a relationship between Leadership Style and Organizational Commitment, possibly because of the belief that "employees who are highly committed to top management will contribute big profits for shareholders".

\section{Effect of Transglobal Leadership (X1) on Employee Performance (Y4)}

Based on the results of the analysis, Transglobal leadership has a significant effect on employee performance. This means that the higher the value of Transglobal Leadership, the higher the value of employee performance.

These findings support Hall's (1996) statement that organizational leadership directly or indirectly affects employee performance. The role of the leader will support the competency process, and employee creativity, in the end, the employees will achieve their best performance and develop. Cohen (1999) states that transglobal leadership is the ability to change a person to grow, change to lead, including assessing the interrelated drive to meet the needs of employees and respect them, so that transglobal leadership can improve employee and company performance and company goals can be achieved better. This finding extends to Hayward (2005) who found that there is a relationship between Employee Performance, Leadership, and Emotional Intelligence in parastatal firms in South Africa.

In line with the behavioral typology of Astabrata leaders, it is fully related to transglobal leadership intelligence. Leader's behavior follows the paths of the sun, moon, stars, wind, clouds, fire, ocean, and earth; leaders must have a sixth intact intelligence such as cognitive intelligence (IQ), emotional intelligence (EI), moral intelligence (SI), cultural intelligence (CI), business intelligence (BI), and especially global intelligence (GI). Astabrata's elaboration and its relationship with leadership intelligence are described as follows: (1) the path of the sun; the sun is hot and full of energy. It provides the means of life. This means that every leader must be able to encourage, give life, and give energy to society. This behavior requires SI, CI, and GI. (2) Moon line; a beautiful moon can light up the darkness. That is, every leader must please and enlighten his people in the dark; a leader who can shine in the dark serves as the moon in chaos due to chaos. (3) The path of the star; apart from being beautiful, the star also provides a compass, direction, and direction. This means that the leader must be a role model and guide. (4) The path of the wind; the wind is everywhere, in every inch of the room. This means that leaders must act carefully, decisively, and go out into the field to explore the lives of their subordinates. (5) Overcast path; It means, scary, but once it rains there is a blessing. This means that a leader must be authoritative but his actions must be beneficial for the lives of his people. (6) The path of the fire; the fire is upright and capable of burning whatever is near it. This means that a leader must be able to act fairly, have principles, be upright without discrimination. (7) Ocean routes; wide and flat oceans. This means that a leader must have a broad view and be able to accept problems and not feel hatred towards anyone. (8) Earth path; The earth is calm and holy. This means that every leader must be able to function like the earth, which is to have a calm, honest character and be willing to give gifts to subordinates who contribute. 
Siagian (1985) regarding the type of leadership of Ki Hajar Dewantoro, the concept of thinking about leadership includes three philosophies which can be said to have covered the dimensions needed in leadership. Transglobal leadership thus includes all aspects, including the leadership of the heart (heart character), head (head method), and hands (hand behavior). A leader, like a regional leader in the public world, is also a team leader for his subordinates in the organization, as a partner and director of global business for shareholders. Meanwhile, the three leadership principles of Ki Hajar Dewantoro are as follows: Ing Ngarso Sung Tulodo (in the front gives an example), Ing Madya Mangun Karso (in the middle of guiding), Tut Wuri Handayani (behind is encouraging). Ki Hadjar Dewantara's first leadership principle was Ing Ngarso Sung Tulodo; ahead is setting an example. A leader walks in front of the people they lead towards the desired goal. The relationship between this principle and the five indicators of leadership behavior number 1 and 2. The second principle is Ing Madya Mangun Karso. This means that a leader must equip each member with the ability to recognize self-potential, the ability to utilize, and the ability to learn to continue to increase their potential. In short, leadership means inspiring, motivating, and encouraging oneself or fellow team members to optimize their abilities. The third principle is Tut Wuri Handayani. A leader can be said to be successful if the organization continues to show high achievement and performance even though the leader is not physically present. Great leaders build organizations in such a way that they continue to grow and develop on their own. Successful leaders are those who can become leaders for the life and soul of the people they lead.

\section{Effect of Motivation (Y1) on Employee Performance (Y4)}

Based on the analysis, it is known that motivation has a significant effect on employee performance. This means that the higher the motivation value, the higher the employee's performance. The results of this study support the motivation and work environment that leads to one's performance (Porter $\&$ Lawler, 1968) that a person will make choices with various alternative behaviors and business levels based on the attractiveness that will be obtained as a result. This study extends the findings of Sari and Ja'far (2010) which found a strong positive relationship between Managerial Motivation and Managerial Performance. Empirically the influence of the drive to work well and the freedom to use the means to complete work will affect the ability of employees to complete work that is beneficial to the cooperative.

\section{Effect of Organizational Culture (Y2) on Employee Performance (Y4)}

Based on the analysis, it is known that organizational culture has a significant influence on employee performance. This means that the higher the value of Organizational Culture, the higher the value of Employee Performance. The organizational culture that develops and is well organized within the company will affect increasing employee performance. If the organizational culture must be changed, then the first thing an employee must do is to learn to modify the old culture so that it can affect his performance. These findings also extend to Nystrom (1993), Koesmono (2005), Kartiningsih (2007) who state that organizational culture affects employee performance.

\section{Effect of Organizational Commitment (Y3) on Employee Performance (Y4)}

Based on the results of the analysis, it is known that organizational commitment has no significant effect on employee performance. This means that each value of organizational commitment will not affect the value of employee performance because employee salaries are still low so that many employees who work in cooperatives look for companies with higher salaries after they are 
accepted in companies whose salaries are higher than the salaries in the cooperative, they leave the office cooperative.

The results of this study differ from Blau's (1987) social exchange theory which states that high affective commitment leads the organization to good performance with OCB employees. The findings of this study differ from the theory of Meyer et al. (1989) that employees who are wholeheartedly committed to organizational goals will dedicate their efforts to organizational success. This research is also different from Brown and Leigh's (1996) statement that organizational commitment is an ongoing process. Besides, individual experiences with organizations are not in line with the findings of Rostini et al., (2020) which state that competitiveness development is not sufficient to be able to improve performance, without commitment. In general, a higher commitment will increase performance. However, Steers (1977) found a weak relationship between commitment and performance.

The factors that cause organizational commitment not to have a significant effect on employee performance are because some employees feel dissatisfied with their salaries so that they easily quit and move (turnover intention) to work for other organizational jobs because employees feel disadvantaged. According to Ramlawati et el. (2020), there are many reasons for wanting to move (turnover intention) including the desire to get a better job. Among the factors causing the desire of company employees to leave the workplace are external factors, such as work environment, stress, and job satisfaction.

\section{Conclusion}

The results of seven hypothesis testing indicate that six hypotheses were confirmed and have a significant effect: transglobal leadership on organizational culture, transglobal leadership towards organizational commitment, transglobal leadership on employee performance, motivation for employee performance, and organizational culture on employee performance. The analysis revealed that one hypothesis was not supported as there was no significant effect of organizational commitment on employee performance.

This research was only conducted in 42 cooperatives in government agencies in Makassar City, South Sulawesi Province with 418 employees, so researchers should use longitudinal data to enrich and deepen research as well as take other collaborative objects. Cooperative leaders and administrators also need to pay more attention to relationships with customers, review employee salaries and increase understanding of shared values and meanings, increase understanding of aspects of work, and increase employee positive attitudes.

The contribution of this research is to test the performance of cooperative employees in Makassar City, South Sulawesi Province. The existence of cooperatives in Indonesia can be felt because they can help cooperative members provide both in the form of money and goods needed by their members. Without a cooperative in a government agency, employees will find it difficult if they need loans in the form of money and goods needed by employees. This study found that organizational commitment has no significant effect on employee performance. This means that the management of cooperatives at government institutions in Makassar City is not optimal, especially the payroll system which is still low so that it affects organizational commitment which in turn affects employee performance. Low organizational commitment can affect turnover intention because employees are dissatisfied with organizational rewards so that it affects employee performance. The results of our interviews with respondents indicate that the salaries of cooperative employees are still minimal, which causes low organizational commitment. 
To improve employee performance in cooperative units in government agencies in the city of Makassar, it is not enough if the leadership only motivates subordinates, treats them as whole individuals, and respects the caring attitude of subordinates to the organization without providing adequate rewards. But leaders must also be able to find ways for employees to survive and be loyal to the organization.

\section{References}

Agarwal, U. A. (2013). Examining the impact of social exchange relationships on innovative work behavior. Team Performance Management, 20(3), 102-120.

Allen, N. J., Meyer, J. P, \& Smith, C. (1993). Commitment organizations and occupations: Extension and test of a threecomponent conceptualization. Journal of Applied Psychology, 87, 538-551

Anoraga, P. (2008). Koperasi, kewirausahaan dan usaha kecil [Cooperatives, entrepreneurship and small business]. Jakarta: Rineka Cipta.

Avolio, B. J., \& Bass, B. M. (2004). Multi-factor leadership questionnaire, manual and sampler set. (3rd ed.). Mind Garden, Inc

Bateman, T. S., \& Strasser, S. (1984). A longitudinal analysis of the antecedents of organizational commitment. Academy of Management Journal, 127, 95-112.

Becker, H. S. (1960). Notes on the concept of commitment. American Journal of Sociology, 66, 32-40

Bernadin, H. J., \& Russel, J. E. A, (1993). Human resource management: An experiential approach. USA: McGraw-Hill. Inc

Blau, G. J., \& Boal, K. B (1987). Conceptualizing how job involvement and organizational commitment affect turnover and absenteeism. Academy of Management Review, 12(2), 288-300.

Brown, S. P., \& Leigh, T. W (1996). A new look at psychological climate and its relationship to job involvement, effort, and performance. Journal of Applied Psychology, 81(4), 358-368.

Bono, J. E., \& Judge, T. A (2003). Self-concordance at work: Toward understanding the motivational effects of transglobal leaders. Academy of Management Journal, 46(5), 554-571.

Cohen, A (1999). Relationship among five forms of commitment: An empirical assessment. Journal of Organizational Behavior, 20(4), 285-308.

Drury, S. (2004), Employee perceptions of transglobal leadership: comparisons by level and with job satisfaction and organizational commitment (Unpublished doctoral dissertation). Regent University, Indiana.

Ferdinand., A. (2006). Structural equation modelling dalam penelitian manajemen [Structural equation modeling in management research]. Semarang: Badan Penerbit Universitas Diponegoro.

Fey, C. F., \& Denison, D. N. (2000). Organizational culture and effectiveness: The case of foreign firms in Russia and Sweden. Working Paper Services in Business Administration, 4(5), 32-44.

Friedman, L. M., \& Macaulay., S. (1969). Law and the behavioral sciences. New York: The Bobbs-Merill Company.

Gibson, J. (1982). Organization, behaviour, structure, processes. New York: McGraw Hill Inc.

Greenleaf, R.K. (1970). The servant as leader. Indianapolis: The Robert K Greenleaf Center.

Hall, J. (1996). The competence connection: A blueprint for excellence. Woodlands: Woodstead Press.

Hayward, B. A. (2005). Relationship between employee performance, leadership and emotional intelligence in a South African parastatal organisation (Unpublished master's thesis). Rhodes University, Grahamstown.

Hernawati, A., \& Nasharuddin (2017). Implementation of quality of work life dan keterlibatan pekerjaan berbasis transglobal leadership sebagai upaya strategi pencapaian optimalisasi kinerja karyawan [Implementation of quality of work life and transglobal leadership-based job involvement as strategic efforts to achieve employee performance optimization]. Journal of Research in Economics and Management, 17(2), 163-177.

Kanter, R. (1999). Managing change - the human dimension. Boston. MA: Goodmeasure. 
Kartasasmita, G. (1996). Pembangunan untuk rakyat: Memadukan pertumbuhan dan pemerataan [Development for the people: Integrating growth and equalization]. Jakarta: CIDES

Kartikandari, D. (2002). Pengaruh motivasi, iklim organisasi, EQ dan IQ terhadap kinerja karyawan: Studi kasus DPU dan setda kabupaten bantul [Influence of motivation, organizational climate, EQ and IQ on employee performance: A case study of DPU and Regional Secretariat of Bantul district]. Sinergi, 4(2), 41-48.

Kartiningsih. (2007). Analisis pengaruh budaya organisasi dan interaksi kerja terhadap organisasi dalam meningkatkan kinerja karyawan [Analysis of the influence of organizational culture and work interactions on the organization in improving employee performance] (Unpublished doctoral dissertation). Universitas Diponegoro, Semarang

Koesmono, H. T. (2005). Kepuasan kerja serta kinerja karyawan pada sub sektor industri pengolahan kayu skala menengah di jawa timur karyawan [Job satisfaction and employee performance in the medium-scale wood processing industry sub-sector in East Java]. Jurnal Puslit Universitas Kristen Petra Surabaya, 6(2), 163-175.

Koh, W. L., Steers, R. M., \& Terborg, J. R. (1995). The effects of transglobal leadership on teacher attitudes and student performance in Singapore. Journal of Organization Behavior, 8, 319-333

Kotter, J. P., \& Heskett J. L. (1992). Corporate culture and performance. New York: The Free Press.

Luthans, F. (2001), Organizational behavior (9 $9^{\text {th }}$ ed.). Boston: McGraw Hill.

Luthans, F. (2002). Organizational behavior (7 ${ }^{\text {th }}$ ed.). New York: McGraw-Hill.

Maruyama, G. M. (1998). Basic of structural equation modeling. Thousand Oaks: Sage Publications.

Maslow, A. H. (2010). Motivation and personality. Jakarta: Rajawali.

Meyer, J. P., Paunonen, S. P., Gellaty, I. R., Goffin, R. D., \& Jackson, D. N. (1989). Organizational commitment and job performance: It's the nature of the commitment that counts. Journal of Applied Psychology, 74(8), 152-156.

Meyer, J. P., \& Allen, N. J. (1991). A three-component conceptualization of organizational commitment. Human Resource Management Review, 1,61-89.

Minner. (1998). Organizational behavior: Performance and productivity. New York: Random House Inc.

Mowday, R. T., Porter, L. W., \& Steers, R. M. (1982). Employee organizational linkages: The Psychology of commitment, absenteeism and turnover. New York: Academic Press.

Muheriono, M. (2012). Pengukuran kinerja berbasis kompetensi [Competency-based performance measurement]. Bandung: PT Rajagrafindo Persada.

Muthuveloo, R., \& Rose, R. C. (2005). Typology of organizational commitment. American Journal of Applied Science, 296, 10781081.

Njotoprajitno, R. S. (2011). Peran kepemimpinan, kompetensi sdm, dan pengelolaan manajemen dalam meningkatkan daya saing koperasi di Indonesia [The role of leadership, human resources competence, and management in increasing the competitiveness of cooperatives in Indonesia]. Universitas Kristen Maranatha Bandung.

Nystrom, P. C (1993). Organizational cultures, strategies, and commitments in health care organizations. Health Care Manage Review, 18(4), 43-49.

Office of Cooperatives and SMEs. (2018). 2018 Performance Report. Surabaya: Office of Cooperatives and SMEs, East Java Province.

Pasolong, H. (2008). Kepemimpinan birokrasi [Bureaucratic leadership]. Bandung: CV, Alfabeta.

Porter, L. W., \& Lawler, E. E. (1968). Behavior in organizations. New York: McGraw-Hill Inc.

Ramlawati., R., Trisnawati, E., Yasin., N., \& Kurniawaty, K. (2020). External alternatives, job stress on job satisfaction and employee turnover intention. Management Science Letters, 11(2), 511-518

Robbins, S. P. (2003). Organisational behaviour: Global and South African perspective. Englewood Cliffs: Prentice Hall.

Robbins, S. P., \& Coulter, M. (1993). Organizational behavior concepts controversies, and applications. New Jersey: Prentice Hall International, Inc.

Robbins, S. P. (2006). Perilaku organisasi [Organizational behavior]. Jakarta: Salemba Empat.

Rostini, R., Souisa, W., Masmarulan, R., \& Yasin, N. (2020). Competitiveness development, learning orientation, entrepreneurial commitment and business performance in the silk industry. Management Science Letters, 11(3), 903-908. 
Russell, R. F., \& Stone, A. G. (2002). A review of transglobal leadership attributes: Developing a practical model. Leadership and Organization Development Journal, 23(3), 145-157.

Sari, A. R., \& Ja'far, M. S. (2010). The impact of target setting on managerial motivation and performance. Paper presented at Simposium Nasional Akuntansi XIII. Universitas Jendral Soedirman Purwokerto.

Setyadi, D. (2005). Pengaruh komitmen organisasi dan budaya kerja serta strategi kompetitif dan partisipasi anggota terhadap motivasi kerja koperasi di provinsi kalimantan timur. [The influence of organizational commitment and work culture as well as competitive strategies and member participation on the work motivation of cooperatives in the province of East Kalimantan] (Unpublished doctoral dissertation). Program Pasca Sarjana Universitas Airlangga, Surabaya.

Sharkey, L. D., Razi, N., Cooke, R. A., \& Barge, P. A. (2012). Winning with transglobal leadership: How to find and develop top global talent to build world-class organizations. New York: McGraw Hill Professional.

Siagian, S. P. (1985). Organisasi kepemimpinan dan perilaku adminstrasi [Organizational leadership and administrative behavior]. Jakarta: CV Haji Mas Agung.

Soedjono. S. (2005). Pengaruh budaya organisasi terhadap kinerja organisasi dan kepuasan kerja karyawan pada terminal penumpang umum di Surabaya [Organizational leadership and administrative behavior]. Manajemen dan Usahawan Indonesia, 7(1), 37-58.

Steers, R. M. (1977). Antecedents and outcomes of organizational commitment. Administrative Science Quarterly, 22(5), 46-56.

Sugiyono, P. (2010). Metode penelitian pendidikan pendekatan kuantitatif, kualitatif, dan R\&D [Educational research methods with quantitative, qualitative, and R\&D approaches]. Bandung: Alfabeta

Tichy, N. M. (1982). Managing change strategically: The technical, political, and cultural keys. Organizational Dynamics (Autumn), 59-80.

Vogel, D. (2011). How to motivate public employees? Focusing on leadership as an important motivational factor. Paper presented at the Annual Conference of EGPA, Romania.

Wasti, S. A., \& Can, Ö. (2008). Affective and normative commitment to organization, supervisor, and coworkers: Do collectivist values matter? Journal of Vocational Behavior, 73(3), 404-413.

Yasin, N. A., Ridjal, S., \& Jjufri, M. (2019). Human capital and entrepreneurship and their impact on the productivity of traditional craftsmen. Revista ESPACIOS, 40(04), 8-20. 